\title{
Helping Dutch Neighborhood Watch Schemes to Survive the Rainy Season: Studying Mutual Perceptions on Citizens' and Professionals' Engagement in the Co-Production of Community Safety
}

\author{
Carola van Eijk ${ }^{1}$ (])
}

Published online: 10 November 2017

(C) The Author(s) 2018

\begin{abstract}
Despite the growing research interest in coproduction, some important gaps in our knowledge remain. Current literature is mainly concerned with either the citizens or professionals being involved in co-production, leaving unanswered the question how co-producers and professionals perceive each other's engagement, and how this is reflected in their collaboration. This study aims to answer that question, conducting an exploratory case study on neighborhood watch schemes in a Dutch municipality. Empirical data are collected through group/individual interviews, participant observations, and document analysis. The results show that the perceptions citizens and professionals hold on their co-production partner's engagement indeed impact on the collaboration. Moreover, for actual collaboration to occur, citizens and professionals not only need to be engaged but also to make this engagement visible to their co-production partner. The article concludes with a discussion of the practical implications of these findings.
\end{abstract}

Keywords Co-production of public services - Citizenprofessional collaboration - Community safety . Neighborhood watch schemes - Local government

Update 11 April 2018 The PDF version of this article was reformatted to a larger trim size.

Carola van Eijk

c.j.a.van.eijk@fgga.leidenuniv.nl

1 Institute of Public Administration, Leiden University, P.O. Box 13228, 2501 EE The Hague, The Netherlands

\section{Introduction}

Co-production is booming, both in practice (compare for instance debates on 'Big Society' and 'The Right to Challenge') and scholarly debate. During the past years, the number of studies on the topic of co-production has increased substantially (Osborne et al. 2016). This broadened our insights on issues like who the co-producing partners are, the objectives of co-production, the specific elements of public services or outcomes that are co-produced, the (potential) results/effects of co-production, and how the co-production process is organized (Voorberg et al. 2015; Loeffler and Bovaird 2016). Gradually, scholars also start to address the question why citizens and public professionals are willing and able to co-produce; or, differently phrased, why they engage in co-production of public services (e.g., Van Eijk and Steen 2016; Bovaird et al. 2015; Van Eijk et al. 2017a; Tuurnas 2015).

Earlier studies show that not all citizens and professionals are engaged in co-production equally or for similar reasons (Van Eijk and Steen 2014; Tuurnas 2015). Professionals, for example, differ in the extent to which they are convinced of the importance and impact of co-production, and the extent to which they feel personally involved (Van Eijk et al. 2017a). Differences in levels of engagement in co-production matter, as the literature assumes that the willingness and ability to co-produce has an impact on citizens' and professionals' contribution to the co-production process (Alford 2009), and these contributions, in turn, influence the (beneficial) effects and outcomes of co-production (Ostrom 1996; Loeffler and Hine-Hughes 2013). When co-producers and professionals do not feel engaged with each other and the co-production process, this can hinder the establishment of a co-productive relationship (Williams et al. 2016). 
However, most studies focus on either the citizens or public professionals being involved in co-production. This is surprising, since co-production inherently is about collaboration $^{1}$ between public professionals and citizens (cf. Brandsen and Honingh 2016). Or, in the words by Nabatchi et al. (2017: 4): 'state actors and lay actors work together to produce benefits.' Yet, the current focus in extant literature on either citizens or professionals leaves unanswered the question of how co-producers and professionals perceive each other's engagement, and how this is reflected in their collaboration. To increase our insights regarding this gap of knowledge, this article aims to answer the following research question: How do citizens' and professionals' perceptions of their co-production partners' level of and purposes for engagement influence the collaboration? Answering this question will provide useful tools for citizens and professionals involved in co-production, enabling them to better deal with some of the challenges they face. Insights into the role of engagement in co-production collaboration can, for instance, explain why citizens and professionals sometimes feel disappointed in co-production and how this can be prevented.

The research question will be answered through an indepth case study of Dutch neighborhood watch schemes that operate in one municipality. Neighborhood watch schemes are among the classical examples of co-production (Pestoff 2012; Bovaird 2007; Brudney and England 1983). Studying Dutch neighborhood watch schemes provides the opportunity to investigate different neighborhood watch schemes operating within the same institutional environment of one municipality, and thus including the same levels of support and facilitation provided by this municipality. At the same time, the lack of (strict) regulations allows diversity in the specific setup of the different neighborhood watch schemes within this municipality, and the citizens and professionals involved might be differently engaged.

In the following, I more thoroughly discuss the case and research methods used, and present the empirical data collected through group/individual interviews, participant observations, articles published in local/regional newspapers, and policy documents. Before delving into the

\footnotetext{
1 The term 'collaboration' in this study should not be confused with collaboration as used in inter-organizational collaboration in public services. Inter-organizational collaboration and co-production are sometimes intermingled; yet these are distinct concepts. In interorganizational collaboration, individuals work together across organizational boundaries and on behalf of their organizations, while in co-production the lay actors are individual citizens or groups of individual citizens who do not represent any organization (Sancino and Jacklin-Jarvis 2016). With the term collaboration, I refer to the cooperation between citizens and professionals: the process in which these actors interact and work together to deliver (or 'co-produce') public services.
}

empirical part, I start with a brief review of literature on the co-production of community safety, and co-producers' and professionals' engagement.

\section{Co-Producing Community Safety}

After a first wave of attention in the 1970s/1980s, during the 2000s/2010s particularly, the idea got foothold that public services must be delivered through (individualized) partnerships between citizens and the government, as an alternative to pure governmental or market delivery (Alford 2009). Through co-production, citizens are enabled to directly and actively contribute to public service delivery processes (Brandsen and Honingh 2016). These contributions are often based on voluntary efforts (Brandsen et al. 2012) and can be utilized in different phases of the delivery process, including the planning or designing phase and the actual implementation (Bovaird and Löffler 2012). Citizens' activities can be either directed at core services of the organization (e.g., tenants of housing cooperatives designing/maintaining their homes) or be complementary to service delivery processes (e.g., parents organizing school excursions) (Brandsen and Honingh 2016).

One example is co-production of community safety through neighborhood watch schemes. Neighborhood watch schemes rely on partnerships between the police, citizens, and municipalities with the aim to produce a safe and livable neighborhood. The focus is mostly on prevention of and raising vigilance against crime, and tackling antisocial behavior (cf. CCV 2010). Neighborhood watch schemes can be perceived as co-production in the implementation of core services (Brandsen and Honingh 2016), based on voluntary participation by citizen-co-producers, combined with a large dependency on regular producers (i.e., the police and municipality) (Van Kleef and Van Eijk 2016). Neighborhood watch schemes, for example, lack the authority to make arrests, and need back-up by the police in case a situation turns out violent. Furthermore, neighborhood watch schemes reflect a collective form of co-production, where the efforts of a group of individual citizens are beneficial to the community. 'Regardless of which citizens participate in the service delivery process, the benefits accrue to the city [or neighborhood] as a collectivity' (Brudney and England 1983: 64). This contrasts with individual forms of co-production, where the co-producers often are the direct service users who solely benefit from the co-production activities and it is only the spillover that may generate social benefits (Nabatchi et al. 2017).

Neighborhood watch schemes are a form of community policing: a collaborative form of policing aimed at problem solving by promoting active partnerships between the police, citizens, and eventually public/private agencies like 
(social) housing offices and schools (Kappeler and Gaines 2015; Friedmann 1992; Cordner 2014). The first example of neighborhood watch schemes is found in the USA in the late 1960s. Shortly thereafter the idea spread out over the UK, Canada, and Australia (Bennett et al. 2008). More recently, in several European countries a more prominent and explicit role of citizens in safety issues can be observed as well (Van der Land 2014b). In European countries like Italy and Hungary, local communities fear the citizen patrols because of their aggressive attitude; these patrols are often illegal as they do not operate in collaboration with local authorities (Van der Land 2014a). In other countries, like the Netherlands, the idea of neighborhood watch schemes is quite popular, also among police officers and municipal professionals. In 2016, in almost half of Dutch municipalities a total number of 700 neighborhood watch schemes were active, and this number grows rapidly (Lub 2016).

This growing popularity in the Netherlands can be explained by a long history advocating cooperation in the fight against so-called petty crimes (e.g., bicycle theft, shoplifting) (Van Steden et al. 2011: 438). In the 1980s, the national government proposed that this kind of everyday crime was the result of an erosion of communality and solidarity, and that partnerships in the communities were needed to revitalize social bonds (Van Steden et al. 2011; Van Noije 2012). This statement marks a radical shift toward larger responsibility for safety issues by citizens, making the Netherlands an interesting case to investigate.

Yet, although this might suggest neighborhood watch is subject to (national) policies/regulations, the opposite is true. With growing popularity, local governments are increasingly confronted with the question what is their role vis-à-vis neighborhood watch schemes, for example in terms of setting up specific arrangements or providing (financial) support (Van Noije 2012). The absence of strict policies/regulations causes a wide variety of ways in which neighborhood watch schemes cooperate with municipalities and the police, raising the question how this collaboration can best be organized. '[T]he key to [sustained] successful community policing is the relationship between the patrol officer and the neighborhood they serve' (Bickel 2014). It is assumed that only mutual trust between police officers and citizens, and 'a true spirit of cooperation' can ensure successful implementation of the philosophy behind community policing (Moon and Zager 2007: 493). However, do citizens and professionals of the police and municipality perceive such a spirit of cooperation or engagement with co-production on the side of their coproducing partners? And how is this reflected in their collaboration?

In the following section, I will summarize why, according to co-production literature, citizens and professionals engage in co-production, and how this might impact on their collaborative efforts.

\section{Being Engaged in Co-Production}

For co-production to succeed, citizens' and professionals' engagement with the process and each other seems crucial, as for example hinted upon by Williams et al. (2016). Credible commitment, for example, stimulates both actors to contribute effort to the co-production process and also encourages actors to continue their input at the same or higher level when their co-production partner increases his/ her input (Ostrom 1996).

Recently, co-production literature has started to address the question of why citizens engage in co-production as coproducer; also in the context of safety (e.g., Van Eijk et al. 2017b). Although it is still hard to explain who will and who will not take part in co-production activities (Bovaird et al. 2015), studies do identify a number of factors impacting on co-producers' engagement. Foremost, citizens need to be triggered by the possibility of participating. This is labeled 'salience' and can either concern the importance of the service delivered to oneself or relatives, or to one's neighborhood or community at large (Pestoff 2012). Community-centered and self-centered motivations can help explain this personal and social salience (Van Eijk and Steen 2016). Yet, salience is necessary but not sufficient for citizens to engage in co-production. Citizens also need to be convinced their participation is easy ('ease'), they are able to co-produce ('internal efficacy'), their efforts are worth it as government can/will be responsive ('external efficacy'), and government will perform the required tasks and activities as promised ('trust'). Socioeconomic variables and the social networks citizens are part of impact these considerations (Thijssen and Van Dooren 2016; Bovaird et al. 2015; Van Eijk and Steen 2016; Etgar 2008). In other words, citizens' decision whether or not to engage in co-production is layered: first citizens consider the importance ('salience') of the coproduction process, and second they judge the co-production task and their own competency to contribute to the public service delivery process (the related variables 'ease,' 'internal/external efficacy,' and 'trust') (Van Eijk and Steen 2016).

Gradually, recent studies have started to unravel professionals' engagement as well. In the literature, we find examples of professionals who are open, willing to listen and actively share information, who show they are personally involved with the co-producers and their activities, and who are helpful. Their engagement stimulates citizens to feel trusted and valued by their co-producing partner (Fledderus 2015; Van Eijk and Steen 2016); Etgar (2008) 
even states that co-producers are more likely to get involved in co-production when they expect to find 'empathetic'-or 'engaged'-partners. Studies show that professionals' engagement in co-production is affected by perceptions they hold of their own work activities and the organization they are working for. As a result of the growing interdependency between citizens and professionals (Bovaird 2007; Bovaird et al. 2011), co-production is assumed to impact on professionals' autonomy (Brandsen and Honingh 2013; Moynihan and Thomas 2013). When professionals perceive more autonomy in co-production, this increases the likelihood they are engaged in co-production (Van Eijk et al. 2017a). Furthermore, studies show that organizational culture can be either stimulating or hindering for professionals to feel engaged (Van Eijk et al. 2017a; Tuurnas 2015). Organizational culture manifests itself in institutions, social relations and habits, and originates largely in management or leadership (Normann 2007: 214-215). Spiegel (1987), for example, illustrates how the mayor's sympathy with the co-production dialogue is essential for it to succeed.

An explorative case study on co-production of campus safety at an American university shows the establishment of a co-productive relationship can be hindered when citizens and professionals do not feel engaged with each other (Williams et al. 2016). In line with a more general finding that citizens are often unaware of the role they should take in service delivery processes (Farmer and Stephen 2012: 89 ), the campus students did not perceive themselves as coproducers of campus safety. This reflected in their behavior ('being naïve') and in negative perceptions of police officers. Consequently, students and police officers felt disengaged with each other and perceived an 'us versus them' mentality (Williams et al. 2016). With the exception of this research by Williams et al., however, current co-production literature does not provide a thorough understanding of how the engagement of citizens or professionals is reflected in their collaboration. This article aims to help solve this gap by an in-depth case study on neighborhood watch schemes.

\section{Research Methods}

To increase our insights into how co-producers and professionals perceive each other's engagement and how this is reflected in their collaboration, I conducted an $e x$ ploratory case study. This research design is preferred when examining contemporary events, when relevant behaviors cannot be manipulated, and when the focus is rather on mechanisms and links that needed to be traced over time than on frequencies or incidence (Yin 2003). While the literature reviewed serves as a general basis to understand the main concepts and mechanisms, the empirical data will be leading the analysis, allowing new and relevant variables to pop up. This section elaborates on the case selection, data collection and data analysis.

\section{Case Selection}

For the research, one municipality-hereafter called Stadszicht-was selected. ${ }^{2}$ Stadszicht is located in the western region of the Netherlands, nearby one of the country's four biggest cities, and has 60,000-80,000 residents. Its neighborhoods are quite diverse when it comes to characteristics like income, ethnicity, and type of houses (e.g., cheap, social rental homes versus expensive private properties) (CBS 2017). In the Dutch context, Stadszicht has a relatively long history with neighborhood watch schemes: the first teams started in 2009/2010. Recently, the number of teams increased further, partly because of deliberate efforts by the municipality and the police. As a result, in almost all of the twelve neighborhoods (wijken) one or more neighborhood watch schemes are active (fourteen in total). This makes comparisons among schemes possible. Stadszicht's strategy to promote neighborhood watch schemes also resulted in having a coordinator in the municipal organization; an office that is not so often installed (Van der Land 2014a). Partly due to the efforts by the municipality and the police, the neighborhood watch schemes reflect a mix of being (mainly) initiated by citizens or by the municipality and/or the police.

\section{Data Collection}

In order to increase the study's internal validity, a variety of data sources was used, including individual/group interviews, participant observations, policy documents, articles from local and regional newspapers, twitter messages, and a YouTube video posted by one neighborhood watch scheme. The data were collected between summer 2016 and spring 2017. In this period, I systematically scanned the twitter accounts of the police unit of Stadszicht and the eleven local police officers in this unit to see if they posted messages on neighborhood watch schemes, and checked whether articles appeared in the local and regional newspapers on the topic at hand. The policy documents were derived from Stadszicht's website and through the civil servants being interviewed. Most information, however, was derived from group and individual interviews, and participant observations. Table 1 lists the 35 respondents questioned in the study, who can be divided among three groups: representing the municipality, the police, and

\footnotetext{
2 The real name will not be provided in order to guarantee anonymity of respondents.
} 
Table 1 List of interviewees

\begin{tabular}{|c|c|c|}
\hline Interviewee & Function/Role & $\begin{array}{l}\text { Neighborhood watch } \\
\text { cheme identification label }\end{array}$ \\
\hline \multicolumn{3}{|l|}{ Municipality } \\
\hline 1 & Mayor $1^{\mathrm{a}}$ & \\
\hline 2 & Civil servant $1^{\mathrm{a} / \mathrm{b}}$ & \\
\hline 3 & Civil servant $2^{\mathrm{b}}$ & \\
\hline 4 & Civil servant 3 & \\
\hline 5 & Team coordinator and $\mathrm{BOA} 1^{\mathrm{c}}$ & $\mathrm{G} / \mathrm{H}$ \\
\hline 6 & BOA 2 & $\mathrm{H}$ \\
\hline 7 & BOA 3 & $\mathrm{~B} / \mathrm{K}$ \\
\hline 8 & BOA 4 & $\mathrm{~A} / \mathrm{M}$ \\
\hline 9 & BOA 5 & $\mathrm{E} / \mathrm{I} / \mathrm{N}$ \\
\hline 10 & BOA 6 & $\mathrm{C}$ \\
\hline 11 & Trainer & \\
\hline \multicolumn{3}{|l|}{ Police } \\
\hline 12 & Local police officer 1 & $\mathrm{C} / \mathrm{L}$ \\
\hline 13 & Local police officer 2 & $\mathrm{~B} / \mathrm{F} / \mathrm{K}$ \\
\hline 14 & Local police officer 3 & $\mathrm{~A} / \mathrm{J} / \mathrm{M}$ \\
\hline 15 & $\begin{array}{l}\text { Local police officer } 4 \\
\text { (participant observations: team meeting with } 18 \\
\text { members and patrol with } 3 \text { members }{ }^{\mathrm{d}} \text { ) }\end{array}$ & $\mathrm{L}$ \\
\hline 16 & Former local police officer 1 & $\mathrm{H}$ \\
\hline \multicolumn{3}{|c|}{ Neighborhood watch schemes } \\
\hline 17 & Coordinator 1 & $\mathrm{~L}$ \\
\hline 18 & Coordinator 2 & $\mathrm{H}$ \\
\hline 19 & Coordinator 3 & $\mathrm{~B}$ \\
\hline 20 & (Former) coordinator 4/current planner & $\mathrm{B}$ \\
\hline 21 & Coordinator 5 & $\mathrm{C}$ \\
\hline 22 & Coordinator 6 & A \\
\hline 23 & Member BPT 1 & $\mathrm{H}$ \\
\hline 24 & Member BPT 2 & $\mathrm{H}$ \\
\hline $25-27$ & Member BPT 3-5 (group interview 1) & B \\
\hline $28-29$ & Member BPT 6-7 (group interview 2) ${ }^{\mathrm{e}}$ & A \\
\hline $30-35$ & Member BPT 8-13 (group interview 3) & $\mathrm{L}$ \\
\hline
\end{tabular}

${ }^{\mathrm{a}}$ Interview held at an earlier stage of the broader research project; no literal transcripts were made

${ }^{\mathrm{b}}$ Civil servant 2 took over the job of civil servant 1 , when she left the organization

${ }^{\mathrm{c}} \mathrm{BOA}$ is an abbreviation of buitengewone opsporingsambtenaren (special investigating officer)

${ }^{\mathrm{d}}$ Informal talk held after the patrol was not recorded

${ }^{\mathrm{e}}$ Originally, a third respondent was invited for this group interview

neighborhood watch schemes. In total, 23 semi-structured individual interviews, three group interviews with two to six respondents, and two participant observations were conducted. Before explaining how respondents were selected, first the design of the interviews and observations is clarified.

\section{Design of Interviews/Observations}

Individual interviews were semi-structured: a similar set of questions (specified to respondents' role/function) formed the basis of each interview, yet at the same time I was attentive to new potential topics and asked additional questions for clarification or elaboration where needed (cf. Boeije 2010). Participants of group interviews were invited 
to talk about their engagement in the neighborhood watch scheme in a relaxed and spontaneous atmosphere, and to bring in all issues relevant to them. Discussions among the participants were encouraged, as this can result in more viewpoints popping up. In that sense, the group interviews look similar to focus groups (Morgan 1998). The topics of individual and group interviews included, among others, respondent's own motivation/engagement in co-production; the collaboration between the municipality, the police and neighborhood watch scheme; and the collaboration within the neighborhood watch scheme. Individual and group interviews took from one to one-and-a-half hours each. All interviews were audio-recorded and transcribed.

Participant observations were mostly used as analytic tool. Participating in a team meeting of one of the neighborhood watch schemes and joining them on a patrol (see below) provided an opportunity to get a better grip on the activities and behavior of the people being studied. During observations, the collaboration between neighborhood watch schemes and local police officers was observed in a naturalistic setting. This enhanced the quality of the interpretation of the data collected via other sources (most notably interviews) (cf. DeWalt and DeWalt 2011). Field notes were made using an observation scheme capturing the behavior/attitude and interaction among participants.

\section{Respondents Interviewed/Observed}

The respondents represent Stadszicht's municipality, police, and neighborhood watch schemes. In the municipal organization, I interviewed (1) the mayor, (2) all civil servants responsible for policies on public order and safety and for contacts with neighborhood watch schemes, (3) the trainer hired to teach the members of neighborhood watch schemes some basic skills, and (4) six special investigating officers (buitengewone opsporingsambtenaren, hereafter: BOA). BOAs are responsible for the enforcement of issues like parking, garbage, dog dirt, and closing hours of cafes/ restaurants. Since September 2015, every neighborhood watch scheme is connected with one BOA. Since there are eight BOAs in office in Stadszicht, this means that some BOAs are assigned multiple neighborhood watch schemes. I invited all BOAs, yet two of them did not want to participate because they were in office for a very short time and/or had not been in touch with their neighborhood watch scheme to provide me with useful information.

In Stadszicht's police unit, eleven local police officers (wijkagenten) are in office. Local police officers are connected with one or more specific neighborhoods, serve as the central contract point for their residents, and are responsible for a wide variety of police tasks such as social problems and nuisance, small crimes and environmental issues. Performing these tasks, local police officers are in close contact with municipalities and several social organizations (Politie 2017). During the past years, the Dutch police have been confronted with several (national) cutbacks. Given the resulting understaffed situation in Stadszicht's police unit (both with regard to local police officers and first-line police officers who deal with emergency calls), I was not allowed to invite all eleven local police officers. I selected three local police officers, based on a number of criteria, including their connection with multiple neighborhood watch schemes (to allow comparisons) and some characteristics of the neighborhood watch schemes concerned (see below). A fourth local police officer was involved in two participant observations; after the observations I had an informal talk with him. The local police chief also brought me in touch with a former local police officer-now being stationed in another police unit-who was involved in setting up Stadszicht's first neighborhood watch scheme. Although I interviewed only a selection of police officers, I do not expect additional interviews would have resulted in additional insights: the interviews with these five police officers became repetitive in nature indicating the main perceptions of police officers about the coproduction with neighborhood watch schemes were covered (in other words, I reached the 'saturation point' (Straus and Corbin 1998)).

The final group of interviewees represents the neighborhood watch schemes. In Stadszicht, fourteen neighborhood watch schemes are active. These are called Buurtpreventieteams (neighborhood prevention teams, hereafter: BPT) and in this article labeled $A-N$. Some BPTs are connected with an entire neighborhood; others operate in smaller parts of it (a sub-neighborhood or buurt). For practical reasons it was not possible to include all BPTs in this study. In order to get many different perspectives, a selection was made in such a way that it includes BPTs who started recently $(A, L)$ or some years ago $(H)$, who are active in problematic $(J)$ or quiet neighborhoods $(C)$, and who are exemplary in professionals' perception $(B, H)$ or are operating with difficulties $(F, J)$. I added to this selection two more BPTs $(K, M)$ of which I interviewed both the BOA and local police officer.

The coordinators of these nine BPTs were invited for an individual, semi-structured interview. Two coordinators were not willing to participate, as they told me their BPT $(F, J)$ (almost) discontinued. Two other BPTs $(K, M)$ did not respond to my invitations. As BPT $K$ and $M$ were added later on to the selection, their non-response cannot create a bias to the research findings; the non-response of BPT $F$ and $J$ might, however, have done so as these BPTs could have provided more insights in why BPTs discontinue. This should be marked as one of the study's limitations.

After contacting the coordinator, I asked him/her to invite some 'regular' members-without any 
Table 2 Distribution of interviewees to neighborhood watch schemes (BPTs)

\begin{tabular}{llllll}
\hline Neighborhood & BOA & $\begin{array}{l}\text { Local police } \\
\text { officer }\end{array}$ & BPT & $\begin{array}{c}\text { Participant } \\
\text { observation }\end{array}$ \\
\cline { 3 - 5 } A & & Coordinator & Regular members & \\
B & $\times$ & $\times$ & $\times$ & $\times$ & $\times$ \\
C & $\times$ & $\times$ & $\times$ & \\
D & $\times$ & $\times$ & $\times$ & \\
E & $\times$ & & & \\
F & $\times$ & $\times$ & Discontinued & \\
G & $\times$ & $\times$ & & \\
H & $\times$ & & $\times$ & \\
I & $\times$ & $\times$ & (Almost) discontinued & \\
J & $\times$ & $\times$ & No response & \\
K & $\times$ & $\times$ & $\times$ \\
L & $\times$ & $\times$ & No response & \\
M & & & & \\
$\mathrm{N}$ & & & & \\
\hline
\end{tabular}

administrative responsibilities such as planning patrols and managing funds as treasurer-to participate in an individual or group interview. Although this selection strategy might potentially result in a bias (due to the role of the coordinator and potential self-selection of enthusiastic members), this was the only alternative available since the contact details of regular members are not publicly available. After the invitation was sent out, one BPT $(C)$ decided that only the coordinator was to participate in the research. In the other four BPTs $(A, B, H, L)$ between two and six members responded. It should be noted that some BPTs are larger compared to others; some have only eight members (including coordinator, planner and treasurer), while others have over 30 regular members. When two members responded, I held two separate interviews; when three or more respondents participated, I organized a group interview for logistical reasons. As during coding of the conducted interviews with both coordinators and regular members no new information emerged, I decided it was not necessary to further expand the number of invited neighborhood watch schemes (cf. Guest et al. 2006).

Finally, BPT $L$ invited me to join them in one of their (bi)monthly team meetings. At this meeting, the eighteen members and local police officer evaluated past patrols and settled the focus for the upcoming months. After this meeting, the local police officer invited me to join him when he accompanied three members of BPT $L$ on their patrol. Table 2 summarizes the link between neighborhood watch schemes and interviewees.

\section{Data Analysis}

Ensuring scientific rigor in qualitative research, the coding process of the collected data is pivotal (Boeije 2010). Therefore, considerable attention was paid to coding the interviews. The coding was conducted using the soft-ware program Atlas.ti. To ensure inter-rater reliability, a selection of six interviews was coded both by the author and a research assistant who also transcribed all interviews. When differences in interpretation existed, a shared interpretation was established. The coding of the empirical data started from the coding scheme presented in Fig. 1, which was established based on the literature review.

\section{Professionals and Citizens Collaborating in Stadszicht}

This section presents the empirical data structured along two timelines: starting a neighborhood watch scheme and continuing it over time. ${ }^{3}$

\section{Starting BPTs: Importance of Professional Guidance}

BPTs in Stadszicht are initiated by both citizens and the municipality, often after concrete incidents occurred like burglaries or troubles with youth hanging around (Stadszicht 2015). After the idea is suggested, the BPT needs to be founded. The interviews show this is a crucial moment:

\footnotetext{
${ }^{3}$ Interview quotes used to support the analysis-in Italics-are translated from Dutch.
} 


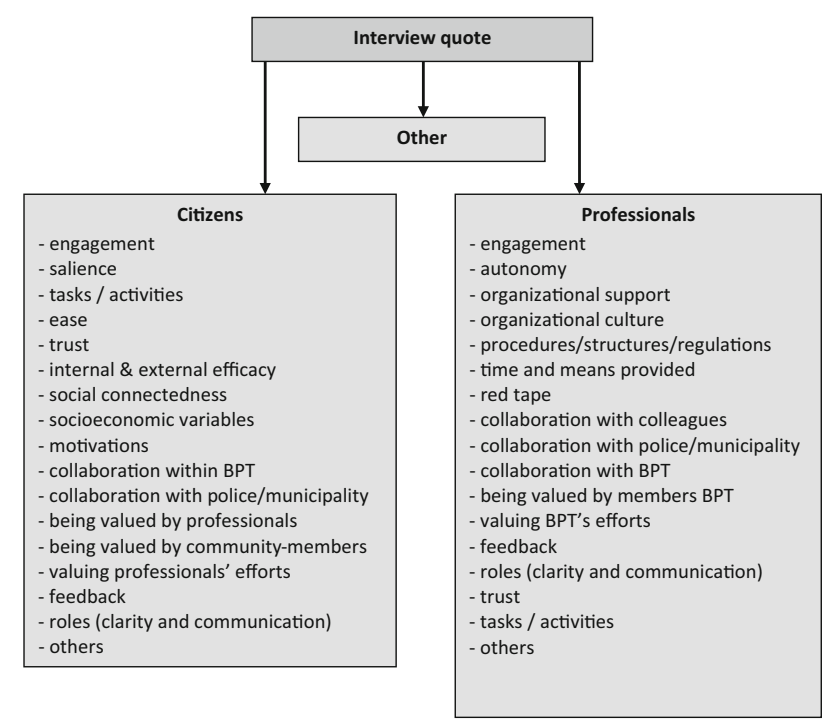

Fig. 1 Coding scheme used for the interviews and participant observations

professional guidance is needed to increase members' safety and to clarify roles, and coordinators and regular members notice the need for an active attitude of the municipality especially to ensure the setup runs smoothly.

First, although members of BPTs are generally not driven by a wish of catching thieves (they mostly focus on livability issues and some even fear potential risks), it is not unlikely they encounter dangerous situations unintentionally. During their patrols, members are highly visible (wearing special jackets, using flashlights, making notes), and 'citizens with bad intentions do generally not distinguish between BPTs and BOAs' (trainer, Interviewee 11). Professional training on how to act in concrete situations is, therefore, crucial. Professional guidance is also needed to clarify what is BPTs' role. Although members are highly visible, their rights do not exceed these of 'ordinary' citizens. So, when members do something they are not allowed to, it is the professionals' task to call them to account for their actions. The professionals interviewed emphasized that situations like this are rare, but do happen sometimes. A local police officer (Interviewee 14) illustrated:

A couple of years ago we started BPT $J$. At that time, some members hold completely different viewpoints on what is a neighborhood watch scheme. To provide an example, young people that were perceived as suspicious were requested to show proof of their identity. But they [BPT members] are not allowed to do so at all! These issues are discussed with the BPT; the mayor also has been involved. In the end, a couple of members were urged to leave the BPT.
To clarify roles, all coordinators in Stadszicht are requested to sign a covenant, and each BPT member must follow the first part of the training program and have a test-patrol with the local police officer before starting their activities.

Second, the municipality's active attitude is crucial for establishing a BPT. In addition to signing the covenant, being in training and attending test-patrols, some practical issues need to be arranged like distributing jackets/notebooks/flashlights, hiring a space to store this stuff and organize meetings, opening an account with a bank to pay rent, and ensuring (potential) members are screened by the police. Although coordinators and regular members agreed most of these activities are useful, they emphasized it is also burdensome ('Setting-up a team is most problematic,' Interviewee 19-20). Often they have to await the municipality's response. BPT $A$ even mentioned it took about 1 year before they were able to start. Some initiatives to start a BPT did not survive this phase: members drop out before the BPT is officially installed. An active attitude of the municipality is required to keep the members motivated; as the former local police officer (Interviewee 16) said: 'You should actively think along with them.' Though, it seems the civil servant was sympathetic toward and convinced of the importance of BPTs, due to the growth in BPTs she was no longer able to manage everything alone. For that reason, an additional employee was added to the municipal department. Several respondents from BPTs and the police mentioned the situation improved: the civil servant who is now daily in touch with the BPTs is enthusiastic and responds fast. In turn, this civil servant (Interviewee 4) mentioned being inspired by the enthusiasm of the BPTs:

Recently, we installed a couple of BPTs. One of these wants to professionalize itself. Three members (treasurer, coordinator and planner) established a committee. They want to improve all kind of things; 'can we do this or that as well?' It proves very infectious. Then I also think 'ok, let's see whether we can grab'.

\section{Continuing BPTs Over Time}

\section{Valuing Each Other's Efforts}

Once the BPT is officially installed, the members start their activities. According to the mayor (Interviewee 1), the beginning is the easiest because people are willing and enthusiastic, 'however, then comes the moment you have to survive the rainy season.' The latter might be taken literally: especially the first rainy (or winter) season is difficult to survive. Some members drop out because of the weather, and they are not convinced their membership can 
contribute anything useful. Often, nothing special happens during patrols, they can pay attention to a smaller range of issues (e.g., overhanging trees and open windows are rarely observed), and the chance of meeting other residents is small. Contact with fellow residents can be more easily established during summer (when everyone is outside also in the evenings) and almost all respondents of BPTs mentioned that if you want to increase residents' safety perceptions, it is important they can see you. Moreover, the interviewees feel valued by residents for their activities in the BPT.

Interviews and participant observations show, however, that not only fellow residents' signs of appreciation are important to keep members continuing their efforts. Coordinators and regular members want to be taken seriously and valued by the professionals. Signs of appreciation are derived from explicitly mentioned statements (e.g., the police officer's 'well done' during one of the participant observations) or from professionals' efforts and activities performed. In this respect, almost all members appreciated information meetings and drinks organized by the municipality, and positively evaluated the attention given by the mayor to BPTs (for instance in the local newspaper). The efforts currently provided by BOAs, however, were negatively evaluated by almost all members. Interviewees 25-27 stated:

We also have a dysfunctioning BOA. That doesn't pep up BOAs' image. Our BOA is also not visible. I would think the BOA is in our neighborhood on a daily basis; to observe and to respond to issues. But our BOA is only sitting behind his desk, I guess. I don't know. But we don't see him. It's really a waste of money.

Some members considered it as a lost opportunity that they have not yet or only once met their BOA: they believed BOAs can provide additional feedback and teach the members important skills (for example, when he joins the members on their patrols). Since local police officers are not always able to do so because of time constraints, they hoped the BOA could fill in this gap.

Respondents felt valued to different extents when it comes to the civil servants and police. Some respondents noticed civil servants can do more, such as attending meetings or giving feedback on reports they write after patrols to share findings with the municipality/police. One of the coordinators (Interviewee 17) noted:

Then I asked, for example, whether we also had to send the reports to them [civil servants]. Then they literally responded like: 'Oh well, if you think it's nice to do so...' In other words, I'm not interested in it. But then I think: when I send the reports to you, you should also have a look at them and do something with it. Until now, nothing happened.

Some interviewees were positive about the contact they have with the police unit. They appreciated to be regularly updated by email, and perceived the police as being open, having a collaborative attitude, and being engaged with BPTs. One of the coordinators (Interviewee 21) was, conversely, not satisfied with the efforts of the local police officer who is currently connected with his BPT: because he does not spontaneously call/email the BPT like the former police officer did, the members start questioning why they are patrolling. Other respondents referred to the understaffed situation in the police unit: due to this, local police officers are often not able to join members on their patrols, while these efforts are highly valued. Moreover, local police officers often switch to another neighborhood or even police unit; some BPTs have been linked with four or five different local police officers in a period of 2 years. This negatively impacts on the trust relation between police officer and BPT.

Almost all members mentioned that feedback on their reports is important, among others to see that their efforts are useful. However, a majority of interviewed professionals complained about the quality of the reports sent by some of the BPTs. A local police officer (Interviewee 13) compared two of his BPTs. While reports sent by BPT $F$ often only include some keywords like 'youth, 10.00 p.m., conversation' and sometimes have to be read twice in order to understand what is listed, BPT $B$ :

describes the entire situation in great details... 'We have been engaged in conversation with a group of young people (between 15 and 17 years old) in the park. There was some alcohol, and we discussed this with them. Furthermore, someone was smoking a joint'.

'Badly written reports' are not only difficult to respond to; some professionals were even afraid members' efforts are useless when they do not provide proper reports. Reports are crucial to the output of BPTs as the information can be highly relevant to the police (even at later moments). With low quality reports, local police officers might get the impression they do not receive anything in return for their efforts. The team coordinator of the BOAs (Interviewee 5) stated:

When BPTs are asking a lot, but local police officers don't see anything in return, I can imagine police officers perceive they have to put in too much time, effort and energy in the collaboration. In the end, they will no longer try so hard. 


\section{Professionals Evaluating Collaboration}

BOAs did not understand why they are connected with BPTs. Except for the team coordinator, none of the interviewed BOAs was convinced the collaboration with BPTs can add something useful to their daily work. BOAs arecontrarily to local police officers-active in the entire municipality, and information provided by BPTs is not directly needed to perform their tasks. Moreover, announcements that are useful can more easily be sent to the central municipal system (similarly to announcement made by 'ordinary' citizens). BOAs perceived the connection between them and BPTs as a superior order. A BOA (Interviewee 7) mentioned:

We have had a meeting once, about what is a BPT and how it works. But they did not explicitly ask things like: 'What do you think you can and want to do?' They did ask our opinion on BPTs. Well... I have to say: at the beginning I was reserved. I already had quite a few tasks. And then this was added with two BPTs. So, I thought I would not have enough time to fill in my role as they at the other side would expect me to do.

Currently, most BOAs mentioned they are scarcely in touch with their BPT and they are fine with that.

Generally, local police officers are more often in touch with their BPT. The former police officer (Interviewee 16) observed a change in the mindset of the police unit: at the time the first BPT was established, the police organization 'had to get used to this new phenomenon.' Some local police officers and officers at the management level were afraid collaboration with BPTs would increase the (already high) workload, because they expected more things would be reported to the police, and police officers had to keep in touch with BPTs for instance to clarify roles. Their concern was strengthened by the rapid growth in the number of BPTs in the years afterward. Nowadays, the workload is perceived less to what was expected: information provided by BPTs is also helpful to local police officers' daily activities, and police officers perceive high levels of autonomy, giving them the opportunity to change timetables and organize contact with BPTs in such a way that fits with their other activities. In the time period studied, the police unit expressed its support for BPTs, for example via the local newspaper (the weekly police message regularly includes something about BPTs) and Twitter (e.g., the local police chief retweeted a photograph of a local police officer patrolling with his BPT: 'Nice, collaborating with residents to improve safety').

However, individual local police officers expressed different attitudes toward the BPT. One local police officer (Interviewee 13) stated:
My colleague, for example, has a dislike for it. By contrast, I think it's very important they [BPT] know who I am. Or that I know who they are. He thinks it's nonsense and unpleasant to walk along with the BPT every two months. He thinks it's no police-related task, conversely to me. But that's just our types of personalities.

The attitude of Interviewee 13 is shared by most interviewed local police officers and seems to be in line with the police unit's strategy. Collaboration with BPTs is perceived as being of added value, yet at the same time BPTs are considered as a 'citizen initiative,' implying they act independently of the police. Local police officers are supportive if needed, for instance when BPTs announce certain troubles. They also try to keep members motivated, for example by asking them to look at specific issues during their patrols or by involving them in specific campaigns in the neighborhood (e.g., increasing awareness among residents of burglaries during vacancies). A third, and final, attitude is reflected by the former local police officer (Interviewee 16): he advocated stronger ties between BPT and police officers, among others to provide them with the skills needed and to make sure 'they have a story to tell to their family and friends.' The BPT 'felt like family' to him, and although he is now stationed in another police unit, he is still in touch with the members.

All the local police officers interviewed marked members' diverse drives and backgrounds (like level of education, age, competencies). Some members are strongly driven by a wish to solve concrete problems like burglaries or youth hanging around; others became members 'by accident' often after they were asked to participate ('I sort of blindly joined in,' Interviewees 28-29). Members who decided to join more incidentally are often retired persons, who perceived their membership as a way to increase their own social contacts or to improve their own health (regular patrols ensures 'you keep moving,' Interviewee 24). Local police officers perceive the effects of these dissimilarities in engagement differently. Two local police officers (Interviewees 12 and 14) agreed that in the end all members share the same goal of making their community a better place to live in, but that individual members differ in how they approach situations (e.g., how to communicate with youth) or in their attitude (e.g., active versus awaiting (professional) pressure). Another local police officer (Interviewee 13) marked that differences do not only occur in but also across BPTs, particularly with regard to how members perceive their own and the police's role. Some BPTs/members want to do as much as possible, while others want to keep their efforts as minimal as possible; some perceive the police as supportive partners, while others are highly dependent on the police and only want to 
invest efforts if the police are considered to be active enough. Local police officers should approach these BPTs and members differently, for instance by pushing them more or less or by making it visible that they are performing important tasks.

\section{Discussion}

This study builds upon recent co-production literature that investigates drivers for citizens and professionals to engage in co-production of public services. In existing literature, insights on how differences in levels of and purposes for engagement impacts on the collaboration remain limited, with most current studies focusing on either citizens' or professionals' perspectives. This article presents an exploratory case study on the engagement and collaborative efforts of both citizens and professionals in the context of community safety. In a Dutch municipality, I studied how members of different neighborhood watch schemes, municipal professionals and police officers perceived their co-production partners' engagement, and how these perceptions impacted on the collaboration.

Based on the analysis, four observations can be made. First, this study shows that, in a case in which citizens' participation is voluntarily, citizens do not only have different purposes for engagement but also show different levels of engagement. Previous studies mainly focused on the purposes behind citizens' engagement (cf. Bovaird et al. 2015; Thijssen and Van Dooren 2016; Van Eijk and Steen 2014), thereby not (explicitly) taking into account that citizens might not all be motivated to the same extent. The citizens being interviewed differ in what drives them to co-produce, but also in how they perceive their role and how much effort they are willing to invest.

Second, differences are observed between the start-up phase and the period afterward in which collaboration between professionals and neighborhood watch schemes is continued. To start with, citizens mention the difficulties of organizing a BPT especially in the start-up phase. They do not feel supported enough or even feel hindered by the municipality. Red tape might thus not only be a factor of relevance to professionals' engagement (cf. Van Eijk et al. 2017a) but also to citizens. In the case studied, the start-up phase is crucial: when (municipal) professionals do not actively contribute and collaborate, there is a high risk citizen initiatives are stillborn. This illustrates that although citizens are highly willing to co-produce, this is not sufficient for successful co-production: also the capacity to coproduce is crucial.

Once the collaboration is established, the connection between professionals and BPT members loosens; because professionals emphasize that members have to act independently and/or members value a more autonomous position. However, even in BPTs that were highly professionalized, citizens continued to appreciate professional support since they were not familiar with the tasks they performed and were in need of regular skills training and feedback on what is their role. Confirmation from professionals that they are on the right track is highly appreciated. In other words, co-production is an undertaking for a long(er) period of time, which points at the need for public organizations to enable their professionals to support the co-production process (for example by providing time and means on a longer term).

Third, current literature provides empirical evidence that individual citizens differ with respect to their motivations to engage and their backgrounds (cf. Thijssen and Van Dooren; Van Eijk et al. 2017b). Based on this study, we can add that also among groups of co-producers different viewpoints can be dominant. For example, BPT $C$ is dominated by members being driven by the social element. The coordinator (Interviewee 21) noticed that membership is based on the slogan 'it is good (for the community), cozy (with your fellow members) and healthy (for yourself).' During patrols, the members talk a lot (and loud enough 'so that burglars can hear them from great distance'). Contrarily, the members of BPT $B$ are strongly driven by solving and preventing burglaries. Social contacts are not the main issue here. When a specific purpose is dominant among the members, this is reflected in the general atmosphere in the BPT and also in members' role perceptions: BPT $B$ perceived the police as a partner to reach their goals, while BPT $C$ prefers spontaneous communication with the local police officer in order to keep motivated. For professionals and public organizations engaged in co-production processes, this entails that different citizen groups might prefer different approaches.

Finally, feelings of appreciation are very important; especially for citizens but also for professionals. When actors get the impression their efforts are not valued or no useful output is provided (e.g., useful reports), they might feel less inspired to actively contribute to co-production. Signs of appreciation can be very diverse, like articles in the local newspaper, organized drinks, feedback or spontaneous emails. Yet, the case also shows that appreciation is only shown by professionals who truly feel engaged with co-production. The BOAs are not convinced of the added value of co-production to their work, and their levels of engagement are low. This hinders the collaboration: members do not feel valued by BOAs and, vice versa do not value BOAs' efforts. When other professionals involved (like police officers) cannot compensate these feelings of disappointment and dissatisfaction, there is a high risk of citizens discontinuing their co-production activities. Furthermore, the BOAs announced they did not 
Fig. 2 Possible values for the purposes for and levels of engagement

\begin{tabular}{|l|crc|}
\hline \multicolumn{4}{|c|}{ Purpose for engagement } \\
\hline $\begin{array}{l}\text { Local police } \\
\text { officers }\end{array}$ & $\begin{array}{c}\text { 'Dislike' } \\
\text { 'Professionalized' } \\
\text { Supportive but } \\
\text { Citizens }\end{array}$ & $\begin{array}{c}\text { Solice-related task } \\
\text { stressing independent } \\
\text { position } \\
\text { Problem solving }\end{array}$ & 'Socialized' \\
\hline \multicolumn{4}{|c|}{ Social contacts } \\
\hline $\begin{array}{l}\text { Local police } \\
\text { officers } \\
\text { Citizens }\end{array}$ & Low & Level of engagement & High / low \\
\hline
\end{tabular}

have any say in the decision to collaborate with BPTs, nor that their role had been properly explained. The way in which public organizations take decisions to establish coproduction might therefore influence professionals' engagement.

To conclude, citizens' and professionals' perceptions on their co-production partners' engagement impact on the efforts one is willing to invest. When professionals are not convinced of the added value of co-production, do not feel committed, have no open-minded attitude and are not motivated to contribute efforts themselves, citizens will not feel taken seriously and valued. When, vice versa, professionals perceive citizens to have low levels of engagement, they also will reconsider their co-productive efforts. So, true engagement with each other in the co-production process is crucial for establishing and continuing a coproductive relationship; a conclusion that is in line with Williams et al. (2016) study. When partners are no longer engaged and therefore willing to provide efforts, the coproductive relationship will not last long: mutual engagement is required in order to not only survive the rainy but all four seasons.

As Fig. 2 illustrates, such mutual engagement can be hindered when professionals and citizens have different 'scores' in terms of their purposes for and levels of engagement in co-production. The simplified figure shows that in a concrete co-production process a 'mismatch' might occur between the engagement of professionals and citizens. Consider for instance BPT $C$ : while the members highly valued social contacts with their local police officers ('socialized'), they perceived the current local police officer as someone who emphasized an independent position ('professionalized'). So, two propositions for further research are (1) that when professionals and citizens have different purposes for engagement this negatively impacts on the co-production partners' levels of engagement, and (2) that similar purposes yet different levels of engagement also negatively impact on the co-production partners' level of engagement. In both cases, the co-production collaboration is hindered.
This finding links with the idea of 'reciprocity' in coproduction that was advocated mainly in the 2000s.

Co-production is a process: whatever process is necessary to establish a parity between those two worlds. That process may be one of collaboration or confrontation. It may be smooth and cooperative or it may take the form of a dialectic that yields parity (Cahn 2004: 31).

However, when professionals' and citizens' engagement does not match, parity between them hardly occurs; the contact (or lack thereof) between BOAs and BPTs even cannot be described as a 'dialectic.' Parity should not be confused with equality: the co-production partners have their own role and position in the collaboration. Parity refers to a situation of 'giving and receiving' (Boyle and Harris 2009), in which contributions are valued (Cahn 2004), and as such the partners attempt to put their coproduction on a higher plane.

The study's conclusion should be perceived in light of its limitations. First, neighborhood watch schemes are among the classical examples of co-production. Yet, insights from this study cannot be generalized to other coproduction cases without further investigation. This, for example, applies to other types of co-production in which citizens' participation is not voluntary. Second, although this explorative case study is based on different sources, there are some limitations in the chosen research design. All neighborhood watch schemes operate in one municipality; further research can test the findings in the context of other municipalities inside and outside the Netherlands. Furthermore, I have not been able to interview respondents from BPTs that recently discontinued or local police officers with lower levels of engagement. Although interviews with other respondents and document analysis provided useful insights, there is always the potential of a bias. 
Fig. 3 Graphical model presenting the different factors that influence citizenprofessional collaboration in co-production

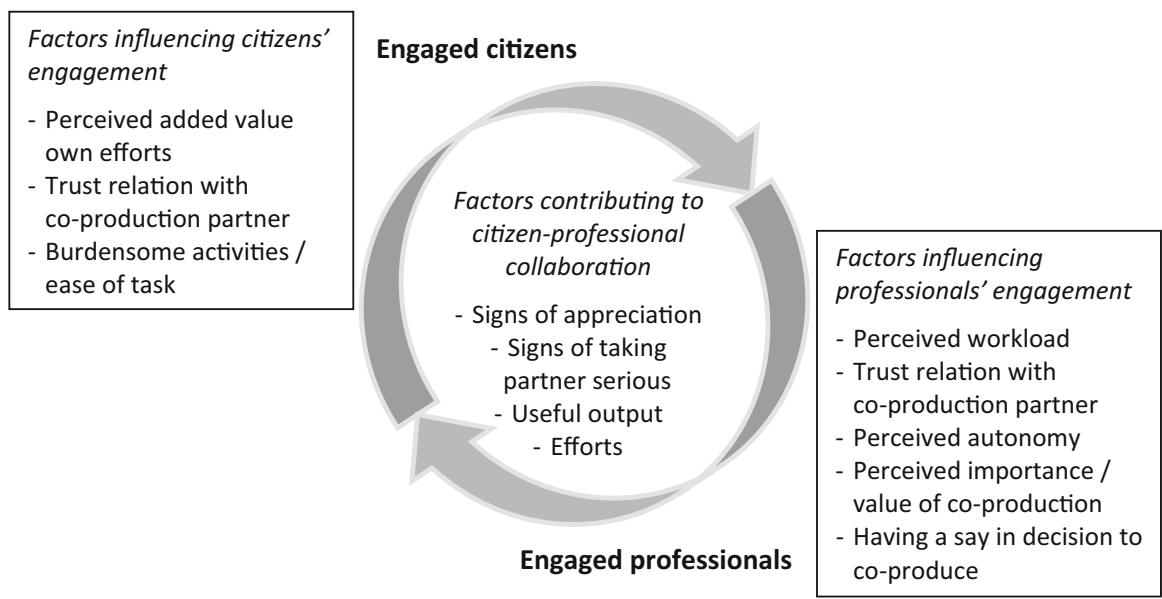

\section{Conclusion}

This study increases our understanding of how mutual perceptions on citizens' and professionals' engagement influence the collaboration. Perhaps the most important finding is that for actual collaboration to occur, citizens and professionals not only need to be engaged but also need to make this engagement visible to their co-production partners. Perceptions citizens and professionals hold on their co-production partners' engagement impact on the efforts one is willing to invest, and, especially in the case of citizens, also on the decision whether to remain involved in the co-production process or not.

Figure 3 schematizes the main factors which influence citizen-professional collaboration in co-production. Citizens' and public professionals' engagement (both levels of and purposes for) is impacted on by different factors, such as perceptions on the added value of co-production and trust relations (remember the regular switches of local police officers). The circle in Fig. 3 shows that high/low engaged citizens and professionals can stimulate/discourage each other; their engagement manifests itself by useful output (e.g., useful reports), signs of appreciation, etc. This visual 'answer' on the research question can be a useful stepping stone for further research on the collaboration between citizens and professionals in co-production, as it presents the key variables that need to be considered in dealing with the relationships between citizens and public professionals in co-production and provide opportunities for hypothesis testing.

The insights have some practical implications. An often heard concern is that citizens and professionals feel disappointed about co-production-or sometimes even resist it strongly (Löffler 2010). Even if co-production is based on voluntary efforts by citizens, the process is not without obligations or free of engagement of both citizens and professionals. Co-production partners need to take their activities and each other seriously. Professionals should clarify what is the citizens' role in the service delivery process, and explain how and under what conditions the citizens' input is valuable; citizens need to be enabled to deliver outputs that are crucial for an effective service delivery process. To motivate citizens, professionals can show how they make use of these outputs and express their appreciation. A made-to-measure approach will be necessary in order to do justice to the capacities and demands of individual co-producers. Finally, public organizations that want to incorporate co-production in public service delivery, need to be aware that professionals can only be truly engaged in co-production if they are convinced of its added value to the delivery process and their daily-work activities. One way to increase this conviction is by involving professionals as early as possible in introducing co-production initiatives.

Acknowledgements The article is embedded in a research talent program called 'The dynamics of co-production at the street-level,' financed by NWO (The Netherlands Organisation for Scientific Research). The author would like to thank Noortje Klarenbeek (Bachelor student Public Administration, Leiden University), who tirelessly transcribed the interviews and assisted in coding the interviews, and Prof. Dr. Trui Steen for her valuable input when conducting this study. She also would like to thank the respondents participating in the research for sharing their experiences, and Dr. Carina Schott and the anonymous reviewers for their valuable feedback on the manuscript.

Funding This paper is part of a Research Talent program called 'The dynamics of co-production at the street-level,' financed by NWO (The Netherlands Organization for Scientific Research).

Open Access This article is distributed under the terms of the Creative Commons Attribution 4.0 International License (http://crea tivecommons.org/licenses/by/4.0/), which permits unrestricted use, distribution, and reproduction in any medium, provided you give appropriate credit to the original author(s) and the source, provide a link to the Creative Commons license, and indicate if changes were made. 


\section{References}

Alford, J. (2009). Engaging public sector clients. From servicedelivery to co-production. Houndmills: Palgrave Macmillan.

Bennett, T., Holloway, K., \& Farrington, D. (2008). The effectiveness of neighborhood watch. Campbell systematic reviews (Vol. 18). Pontypridd: The Campbell Collaboration.

Bickel, K. W. (2014). Are toxic leaders derailing your community policing efforts? The e-newsletter of the COPS Office, Vol. 7 (Issue 3, March). Published at https://cops.usdoj.gov/html/ dispatch/03-2014/toxic_leaders_derailing_your_cp.asp.

Boeije, H. (2010). Analysis in qualitative research. London: Sage.

Bovaird, T. (2007). Beyond engagement and participation: User and community coproduction of public services. Public Administration Review, 67(5), 846-860.

Bovaird, T., \& Löffler, E. (2012). From engagement to co-production. How users and communities contribute to public services. In V. Pestoff, T. Brandsen, \& B. Verschuere (Eds.), New public governance, the third sector and coproduction (pp. 35-60). New York/London: Routledge.

Bovaird, T., Löffler, E., \& Hine-Hughes, F. (2011). From passive customers to active co-producers: The role of co-production in public services. http://www.mycustomer.com/topic/customerexperience/passive-customers-active-co-producers-role-co-pro duction-public-services/1. Accessed March 2013.

Bovaird, T., Van Ryzin, G. G., Loeffler, E., \& Parrado, S. (2015). Activating citizens to participate in collective co-production of public services. Journal of Social Policy, 44(1), 1-23.

Boyle, D., \& Harris, M. (2009). The challenge of co-production. How equal partnerships between professionals and the public are crucial to improving public services. Discussion paper. London: NESTA.

Brandsen, T., \& Honingh, M. (2013). Professionals and shifts in governance. International Journal of Public Administration, 36(12), 876-883.

Brandsen, T., \& Honingh, M. (2016). Distinguishing different types of coproduction: A conceptual analysis based on the classical definitions. Public Administration Review, 76(3), 427-435.

Brandsen, T., Pestoff, V., \& Verschuere, B. (2012). Co-production as a maturing concept. In V. Pestoff, T. Brandsen, \& B. Verschuere (Eds.), New public governance, the third sector and coproduction (pp. 1-9). New York/London: Routledge.

Brudney, J. L., \& England, R. E. (1983). Toward a definition of the coproduction concept. Public Administration Review, 43(1), $59-65$.

Cahn, E. S. (2004) [2002]. No more throw-away people: The coproduction imperative. Washington, DC: Essential Books.

CBS [Statistics Netherlands] (2017). Kerncijfers wijken en buurten. www.staline.cbs.nl/Statweb/publication. Accessed March 2017.

CCV [Centrum voor Criminaliteitspreventie en Veiligheid] (2010). Buurtpreventie. http://www.hetccv.nl/dossiers/wijkinterventies/ buurtpreventie.

Cordner, G. (2014). Community policing. In M. D. Reisig \& R. J. Kane (Eds.), The Oxford handbook of police and policing (pp. 148-171). Oxford: Oxford University Press.

DeWalt, K. M., \& DeWalt, B. R. (2011). Participant observation. A guide for fieldworkers. Lanham: AltaMira Press.

Etgar, M. (2008). A descriptive model of the consumer co-production process. Journal of the Academy of Marketing Science, 36(1), 97-108.

Farmer, J., \& Stephen, K. (2012). Organisational processes and the policy-practice gap. In J. Farmer, C. Hill, \& S.-A. Muñoz (Eds.), Community co-production. Social enterprise in remote and rural communities (pp. 75-92). Cheltenham: Edward Elgar.
Fledderus, J. (2015). Does user co-production of public service delivery increase satisfaction and trust? Evidence from a vignette experiment. International Journal of Public Administration, 38(9), 642-653.

Friedmann, R. R. (1992). Community policing: Comparative perspectives and prospects. New York: St. Martin's Press.

Guest, G., Bunce, A., \& Johnson, L. (2006). How many interviews are enough? Field Methods, 18(1), 59-82.

Kappeler, V. E., \& Gaines, L. K. (2015) [2011]. Community policing. A contemporary perspective. London: Routledge.

Loeffler, E., \& Bovaird, T. (2016). User and community coproduction of public services: What does the evidence tell us? International Journal of Public Administration, 39(13), 1006-1019.

Loeffler, E., \& Hine-Hughes, F. (2013). Five steps to making the transformation to co-production. In E. Loeffler, G. Power, T. Bovaird, \& F. Hine-Hughes (Eds.), Co-production of health and wellbeing in Scotland (pp. 132-137). Birmingham: Governance International.

Löffler, E. (2010). A future research agenda for co-production: Overview paper. In: LARCI (Local Authorities \& Research Councils' Initiative). Co-production: A series of commissioned reports. LARCI Commissioned Summary Report. Published at: http://www.govint.org/fileadmin/user_upload/publications/LARCI_ CoproductionPapers_2010.pdf.

Lub, V. (2016). De burger op wacht. Het fenomeen 'buurtpreventie' onderzocht. Rotterdam: Kenniswerkplaats Leefbare Wijken.

Moon, B., \& Zager, L. J. (2007). Police officers' attitudes toward citizen support. Focus on individual, organizational and neighborhood characteristic factors. Policing: An International Journal of Police Strategies \& Management, 30(3), 484-497.

Morgan, D. L. (1998). The focus group guidebook. Thousand Oaks, CA: Sage.

Moynihan, D. P., \& Thomas, J. C. (2013). Citizen, customer, partner: Rethinking the place of the public in public management. Public Administration Review, 73(6), 786-796.

Nabatchi, T., Sancino, A., \& Sicilia, M. (2017). Varieties of participation in public services: The who, when, and what of coproduction. Public Administration Review, 77(5), 766-776.

Normann, R. (2007) [2002]. Service management. Strategy and leadership in service business. Chichester: John Wiley \& Sons.

Osborne, S. P., Radnor, Z., \& Strokosch, K. (2016). Co-production and the co-creation of value in public services: A suitable case for treatment? Public Management Review, 18(5), 639-653.

Ostrom, E. (1996). Crossing the great divide: Coproduction, synergy, and development. World Development, 24(6), 1073-1087.

Pestoff, V. (2012). Co-production and third sector social services in Europe. In V. Pestoff, T. Brandsen, \& B. Verschuere (Eds.), New public governance, the third sector and coproduction (pp. 13-34). New York/London: Routledge.

Politie (2017). Wijkagent. www.politie.nl/themas/wijkagent. Accessed March 2017.

Sancino, A., \& Jacklin-Jarvis, C. (2016). Co-production and interorganizational collaboration in the provision of public services: A critical discussion. In E. Bracci, M. Fugini, \& M. Sicilia (Eds.), Coproduction of services in the public sector: Experiences and challenges (pp. 13-26). Milano: PoliMI Springer Briefs in Applied Sciences and Technology.

Spiegel, H. B. C. (1987). Coproduction in the context of neighborhood development. Journal of Voluntary Action Research, 16(3), 54-61.

Stadszicht. (2015). Notitie buurtpreventie 2015-2018. Stadszicht: Enforcement Department in the municipal organization of Stadszicht. 
Straus, A., \& Corbin, J. (1998). Basics of qualitative research. Techniques and procedures for developing grounded theory. Thousand Oaks: Sage Publications.

Thijssen, P., \& Van Dooren, W. (2016). Who you are/where you live: Do neighbourhood characteristics explain co-production? International Review of Administrative Sciences, 82(1), 88-109.

Tuurnas, S. P. (2015). Learning to co-produce? The perspective of public service professionals. International Journal of Public Sector Management, 28(7), 583-598.

Van der Land, M. (2014a). De buurtwacht. Naar een balans tussen instrumentalisering en autonomie van burgers in veiligheid. Amsterdam: Vrije Universiteit Amsterdam.

Van der Land, M. (2014b). Citizens policing citizens: Are citizen watches manifestations of contemporary responsible citizenship? Citizenship Studies, 18(3-4), 423-434.

Van Eijk, C. J. A., \& Steen, T. P. S. (2014). Why people co-produce: Analysing citizens' perceptions on co-planning engagement in health care services. Public Management Review, 16(3), $358-382$.

Van Eijk, C. J. A., \& Steen, T. P. S. (2016). Why engage in coproduction of public services? Mixing theory and empirical evidence. International Review of Administrative Sciences, 82(1), 28-46.

Van Eijk, C. J. A., Steen, T. P. S., \& Torenvlied, R. (2017a). Public professionals' engagement in co-production: Dutch elderly care managers' perceptions on collaboration with client councils. Working Paper, Leiden University.

Van Eijk, C. J. A., Steen, T. P. S., \& Verschuere, B. (2017b). Coproducing safety in the local community: A Q-methodology study on the incentives of Belgian and Dutch members of neighbourhood watch schemes. Local Government Studies, 43(3), 323-343.

Van Kleef, D. D., \& Van Eijk, C. J. A. (2016). In or out: Developing a categorization of different types of co-production by using the critical case of Dutch food safety services. International Journal of Public Administration, 39(13), 1044-1055.

Van Noije, L. (2012). Coproductie veiligheid. In V. Veldheer, J.-J. Jonker, L. Van Noije, \& C. Vrooman (Eds.), Een beroep op de burger. Minder verzorgingsstaat, meer eigen verantwoordelijkheid? Sociaal en Cultureel Rapport 2012 (pp. 188-212). Den Haag: Sociaal en Cultureel Planbureau.

Van Steden, R., Van Caem, B., \& Boutellier, H. (2011). The 'hidden strength' of active citizenship: The involvement of local residents in public safety projects. Criminology \& Criminal Justice, 11(5), 433-450.

Voorberg, W., Bekkers, V., \& Tummers, L. (2015). A systematic review of co-creation and co-production. Public Management Review, 17(9), 1333-1357.

Williams, B. N., LePere-Schloop, M., Silk, P. D., \& Hebdon, A. (2016). The co-production of campus safety and security: A case study at the University of Georgia. International Review of Administrative Sciences, 82(1), 110-130.

Yin, R. K. (2003). Case study research. Design and methods. Thousand Oaks, CA: Sage. 